Article

\title{
Adherence to Urban Agriculture in Order to Reach Sustainable Cities; a BWM-WASPAS Approach
}

\author{
Milad Kolagar ${ }^{(D)}$ \\ Department of Industrial Engineering and Management, Shahrood University of Technology, \\ Shahrood 3619995161, Iran; miladkolagar@gmail.com or m.kolagar@shahroodut.ac.ir; Tel.: +98-937-816-0253
}

Received: 29 December 2018; Accepted: 25 January 2019; Published: 27 January 2019

\begin{abstract}
Today, the uncontrolled urban expansion and ever-increasing rise of construction have caused the need for food, urban greenery, and a healthy environment to be felt more than any other time. On the other hand, population growth and the reduced production of agricultural products and food have jeopardized food security in urban areas, which will endanger the sustainable development of cities. However, the main problem, in which many societies are involved, is how to respond to these needs in a sustainable way. One of the ways of responding to these dilemmas in large cities is the purposeful implementation of urban agriculture. Urban agriculture development, as an important issue, requires the adoption of fundamental and logical policies. In this regard, this research was conducted to evaluate the extent of adherence to urban agriculture in Iran's eight densely populated cities using a new combined approach of the best-worst method (BWM) and weighted aggregated sum product assessment (WASPAS). The results indicated that urban agriculture still has a long way to go and should be considered more seriously. Moreover, vertical farming has been suggested as one of the ways of promoting urban agriculture in the country and smoothing the way to sustainable development.
\end{abstract}

Keywords: urban agriculture; sustainable development; best-worst method (BWM); weighted aggregated sum product assessment (WASPAS); vertical farming

\section{Introduction}

In recent years, the idea of green cities has been proposed for the sustainability of urban environments and, as the essence of sustainable urban development, has placed a lot of emphasis on the need to pay attention to the environmental status of cities and the communities' duties towards future generations [1-4]. Green and sustainable cities have clean air, clean water, and clean streets. They also encourage green behavior, such as the use of public transport, and their environmental degradation is relatively low $[5,6]$. One of the most important factors affecting the sustainability of cities is their management in the field of agriculture. In fact, agriculture is one of the most important economic sectors and recognized as one of the foundations for the food security of societies. Unfortunately, mismanagement in this area has had devastating consequences, such as reduced production, increased demand, and severe climate change, and caused food crises in many parts of the world $[7,8]$. In a general view, if the city is being divided into two parts, which consists of its main body and structure and its citizens, it will be determined that the development of the city's body is worthless regardless of the needs and conditions of the citizens. The first human need after air and water is food and today, agricultural production is in difficulty due to the growing population and the shortage of water resources in the world. With the same philosophy and system they used in previous years, farmers cannot meet the needs of today's world in general and of developing countries in particular. Therefore, based on the character of postmodern philosophy, today's world is a combination of tradition, and modernity and agriculture in the current world also need to be 
revised [9]. The overtaking of urban population from the population of villages and the ever-increasing urbanization has changed agricultural practices, one of the most important of which is the forms and methods of urban agriculture [10]. Urban agriculture occurs wherever humans can grow grains even in the smallest part of the soil [11]. This is not only the place of urban agriculture that separates it from traditional and rural agriculture, but more importantly, it is the interactions and coping with an urban ecosystem [12]. Agricultural production in the city does not mean agriculture and cultivation in its general form, but it refers to easy planting and producing microfood products with minimal facilities. Urban agriculture not only generates food supplies in cities but also addresses problems such as poverty, malnutrition, and environmental degradation and provides food security $[13,14]$, while providing many business opportunities for small and medium-sized entrepreneurs [15]. Urban agriculture supports sustainable development goals, including environmental protection, health and nutrition, poverty reduction, building community capabilities, participatory decision making, and economic development of society, and is known as an agile network in pushing and directing citizens towards knowledge and solutions [16]. In other words, today, urban agriculture development can have at least two basic roles: It initially provides food security for urban communities and, in the second step, it will reduce the burden of food supply that affects rural communities.

Activities related to the urban agriculture approach are generally classified in the two groups of uncontrolled environments and controlled environments. Both approaches have been formed to reduce poverty and hunger, create sustainable patterns in the production of food products in pursuit of sustainable development goals, and preserve environmental values [17]. Agriculture in uncontrolled environments refers to any open-air urban agriculture operations and means that there is no control over the environmental conditions and factors affecting the growth of food products in this kind of agriculture [18]. Of the various types of methods for implementing this type of urban agriculture, one can mention the local gardens and farms, green and violet walls outside the buildings, and green roofs. With the expansion of the competitive sector of agricultural industry and the importance of the lack of fertile and cultivated land and, consequently, the reduction of high-quality products, exploiting unused surfaces such as roofs is considered to be one of the most effective methods for improving agricultural production [19]. Williams et al. (2010) concluded that the government's emphasis on creating green roofs in Australian cities is due to the environmental benefits it contains. While the two intensive and extensive types of green roofs are globally recognized, a small number of extensive green roofs have been made in Australia. One of the major obstacles for increasing the widespread use of extensive green roofs (also referred as ecoroofs) in Australia was considered to be the lack of information to evaluate their use in local conditions [20].

Farming in controlled environments is a form of agriculture in which environmental conditions such as light, temperature, humidity, and nutrient cycles are being controlled and associated with urban agriculture and green constructions [21]. Agricultural practices in controlled environments include various types of greenhouses, building farms, and vertical farms. According to the general definition, vertical agriculture refers to the cultivation of plants and even animals inside skyscrapers and high-rise towers or inclined highs in which there is a hydroponic farming system to create synergies between the environment within the building and the agricultural operations, such as multiple plantations in the floors or glass space in front of the buildings [22]. Vertical farming can be defined as a system in which plants, animals, fungi, and other living creatures contribute to the food supply and produce food, fuel, fiber or other products, and they continue to work in a vertical state on each other [23]. Furthermore, the agricultural system in buildings has progressed dramatically over the last 10 years through the use of new technologies, including nonsoil agriculture (hydroponics), aeroponic systems, and drip irrigation systems [24]. One of the most important goals of constructing these vertical farms is to preserve the natural environment, enjoy sufficient food, and cultivate healthy and organic food, which can make significant contributions to the sustainability of communities.

At present, urban agriculture is a small, indigenous world that has more to do with food growth and using innovative ideas to generate income in a limited area of land and putting emphasis on 
direct and non-intermediary purchases [25]; it has become a huge economic force and improved social awareness on issues such as hunger, poverty, and health. In fact, urban agriculture, with proper use of the resources and natural habitat of a city, provides part of the nutritional needs of citizens [26] and leads to environmental and ecological benefits and prevents the destruction of natural resources. It can also increase agrotourism in cases where conditions such as agricultural landscape, accessibility, supporting infrastructure, and public acceptance are available [27], where farmers develop their service by offering food and selling fresh agricultural products to urban tourists. This leads to economic investment and creates new employment opportunities in order to step towards the social and economic dimensions of sustainable development. In this regard, this study aims to examine the extent to which cities are committed to implementing urban agriculture development policies by considering the dimensions affecting it in eight major cities of Iran.

The rest of this paper is structured as follows. Section 2 presents an overview of the dimensions being considered for urban agriculture in Iran. In Section 3, a review of the pertinent preliminaries and research methods, such as the best-worst method, weighted aggregated sum product assessment, and the proposed BWM-WASPAS approach, are explained. Section 4 presents a data analysis case of evaluating and prioritizing eight populous cities of Iran in order to determine how much they adhere to the urban agriculture policies for sustainable development. Finally, Section 5 summarizes the main conclusions.

\section{Sustainable Urban Agriculture in Iran}

Iran, with more than 81 million people, is seeking some ways to provide food security. One of the country's most crucial policies in this field is finding solutions to become self-sufficient in agricultural production. Due to its warm and dry climate, Iran is one of the countries with the highest water demand for agricultural production, and more than 85 percent of the country's water consumption is consumed in agriculture. Meanwhile, Iran's water resources, which are located in a semiarid and arid region of the world, are decreasing annually and achieving the self-sufficiency policy requires more attention to scientific methods of agriculture [28,29]. In other words, if urban communities are able to provide their food in terms of food security and use scientific methods for developing urban agriculture, this could be in line with the country's self-sufficiency policy. In developed countries, the municipalities together with the Ministry of Agriculture have participated in the institutionalization of urban agriculture [30]. Urban agriculture development in Iran also requires multilateral support from relevant organizations, where one of these organizations is the municipality. Moreover, the lack of effective strategic roadmaps in developing urban agriculture is one of the key issues. Therefore, the country is facing challenges in eliminating the need for food and providing food security for the community, especially in big cities. Hence, it is necessary to pay attention to urban areas in addition to paying attention to agriculture in rural areas. Since there is a permanent relationship between man and his environment, sustainable urban agriculture can, by designing spaces that strengthen this relationship, attract people's participation in urban environmental sustainability and respond to a significant portion of the food needs of citizens by managing the use of natural resources. In order to accomplish the mentioned goal, this research considers the following dimensions for sustainable urban agriculture in Iran. In fact, these dimensions are considered to be the consequences of the implementation and adherence to the urban agriculture policies and have been selected in accordance with this research.

\subsection{Environmental Dimension}

Today, climate change and air pollution and its destructive effects on the health of citizens and, in general, making cities unsustainable cannot be neglected by anyone [31]. Urban agriculture can help to reduce air pollution by increasing the urban green spaces per capita, which consequently helps photosynthesis and improves its quality through the use of open spaces, such as roofs. It can also lead to high biodiversity $[32,33]$ and a quiet environment for urban birds and it can be said that 
the formation of small wildlife in cities is due to its other results. Additionally, a lot of energy is spent in many parts of the world in transporting and packing food. Urban agriculture can reduce the need for transportation and packaging through the production of food within the city, and it helps to achieve this after a sustainable development by preserving the environment. It should be noted that attracting the participation of all citizens from all levels and their cooperation in plant breeding and food production creates a sense of attachment in them and prevents them destroying and polluting the environment. All of these have a significant impact on the sustainability of cities and preservation of the environment for future generations.

\subsection{Socioeconomic Dimension}

This dimension states that urban agriculture plays a major role in social development of the community [34]. For example, in Iran's higher education system, 80 percent of agricultural engineers and related disciplines are urbanites, many of whom do not have land for agricultural activities or any interest in participating in production. By providing the necessary facilities for the activities of these people in the field of urban agriculture, which are also related to their specialty and field of study, it will be possible to increase the rate of employment and provide the basis for social participation and increase the efficiency of individuals, as well as to acquire economic benefits and thereby embody the social and economic dimensions of sustainable development. It is worth noticing that the establishment of social relations and the growth of citizens' mental health in the wake of the lack of connection with nature as a result of enjoying urban green nature [35] are the other social benefits of urban agriculture, even for nonspecialists in this field.

\subsection{Vulnerable Members' Empowerment}

Women and children are usually the most vulnerable members in Third World societies. Urban agriculture is attractive to women as a means of promoting food security and making more money and allows them to engage in economic activities while taking care of their children and doing their home affairs [36]. In fact, urban agriculture in countries where solid and traditional beliefs impede the active and effective participation of women in the community can play a supportive role and, with the independence of women, play an effective role in improving their mental health. Obviously, strengthening the sense of self-esteem in the women of a community, as the greatest educators of humanity and the identity builders of every community, will have a direct impact on the mental health of the children and the future of society.

\subsection{Training and Culturing Dimension}

Training in the form of workshops or even with participation in agricultural projects of the city is a kind of cultural development in this field. Farming and gardening enthusiasts can get acquainted with the cultivating plant species according to the climate of their city and produce a percentage of the food they need. The need to educate and promote the culture of environmental protection is one of the most important concerns of today's cities. Starting education from a young age is the best way to promote this culture. Managers and authorities can create training centers for all interested citizens, especially children, through the establishment of educational centers and clinics. Students and children attending such clinics and educational centers or visiting urban farms can get closely acquainted with these activities and become aware of these new products and the harmfulness of packaged and chemical products while participating in these training activities.

\subsection{Supply Dimension}

As stated above, urban agriculture can be a source of income by creating new employment opportunities. Active users in urban agriculture can be divided into two groups. The first group is engaged in this activity to provide a percentage of their family's food and do not intend to enter the market for the sale of these products. The second group, though, in addition to supplying the 
household, intends to sell their products or seek to obtain economic benefits this way. For such people, the platforms and facilities of product supply should be provided by the authorities of the cities. Establishing city-based markets to provide the facilities for the provision of these clean products, with natural and good taste and no harmful chemicals, can be effective in encouraging and attracting the participation of this group. Additionally, all of the dimensions mentioned above and the cities which have been investigated in this study have been demonstrated in Figure 1.

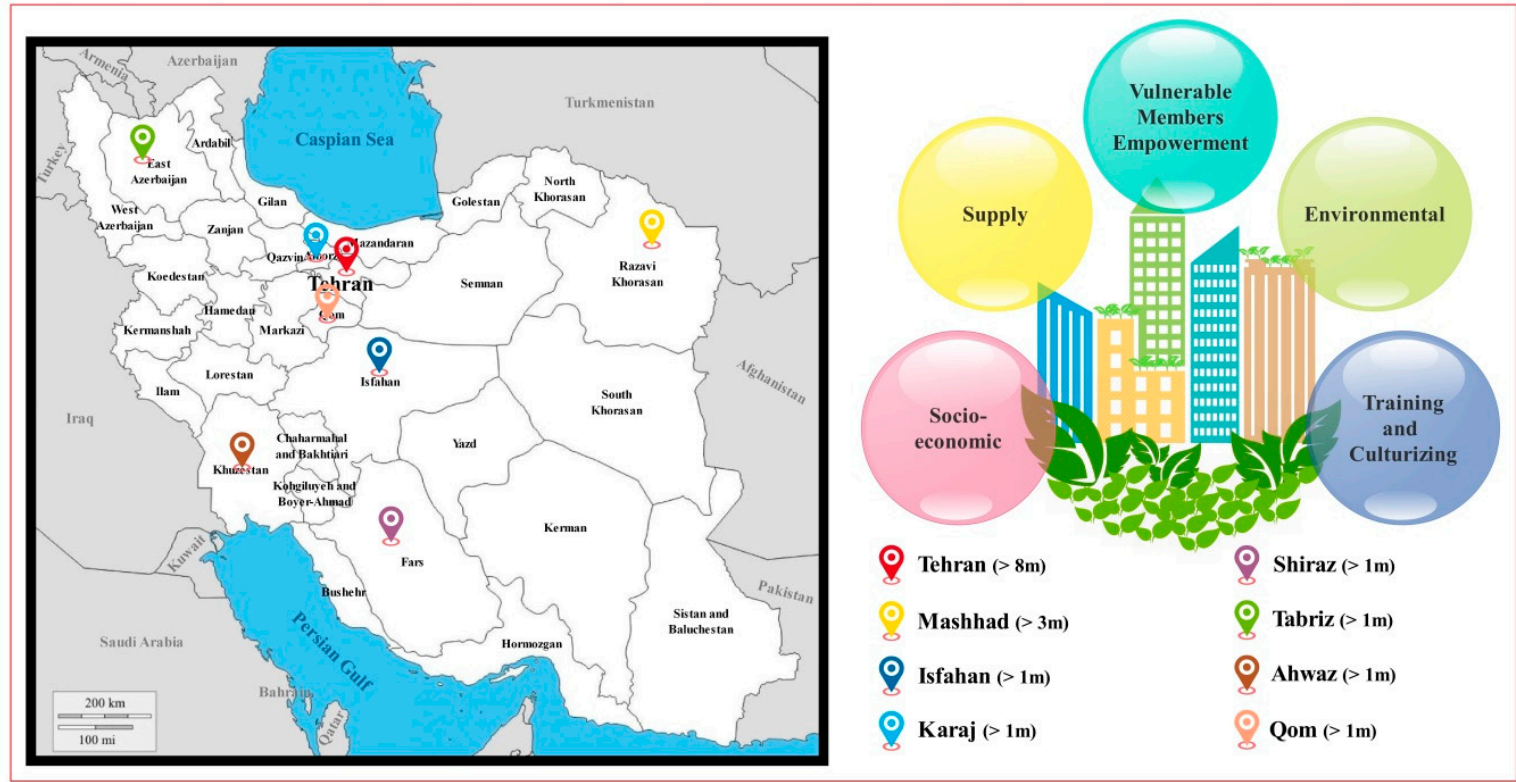

Figure 1. The proposed dimensions for sustainable urban agriculture.

\section{Preliminaries and Method}

\subsection{Best-Worst Method (BWM)}

The best-worst method is a multiple criteria decision making (MCDM) method which was firstly introduced by Rezaei (2015) and has been applied in several areas, such as organizational assessment [37], the airline industry [38,39], the energy sector [40], green innovation [41], logistics [42], and sustainability issues $[43,44]$. Based on this approach, the best and worst attributes are determined by the decision-making team and a pairwise comparison is made between each of these two attributes (best and worst) and other attributes. Then, a MAXIMIN problem is formulated by considering the preference of the best attribute over the other attributes and the preference of the other attributes over the worst one. Then, this model is solved in order to obtain the weights of various attributes. After that, a formula is used to calculate the consistency ratio of the results in order to check the validity of the comparisons and determine if the results are reliable or not. The steps of performing this procedure are as follows [45]:

Step 1: Determining the decision-making attributes. At first, the set of attributes used in the problem should be defined as $\left\{c_{1}, c_{2}, \ldots, c_{n}\right\}$, which are required to make a comprehensive decision.

Step 2: Determining the best (most desirable and most important) and the worst (least desirable and least important) attribute. This means that the decision-making team defines the best and the worst attribute in general without doing any comparisons.

Step 3: Determining the preference of the best attribute over the other attributes using a number between 1 and 9. The preference vector of the best attribute over the other attributes is shown as $A_{B}=\left(a_{B 1}, a_{B 2}, \ldots, a_{B n}\right)$, where $a_{B j}$ indicates the preference of the best attribute (B) over attribute (j), and it is also obvious that $a_{B B}=1$. 
Step 4: Determining the preference of all attributes over the worst attribute using a number between 1 and 9. The preference vector of other attributes over the worst attribute is shown as $A_{W}=\left(a_{1 W}, a_{2 W}, \ldots, a_{n W}\right)^{T}$, where $a_{j W}$ indicates the preference of attribute (j) over the worst attribute $(\mathrm{W})$, and it is also obvious that $a_{W W}=1$.

Step 5: Calculating the optimal weights $\left(w_{1}^{*}, w_{2}^{*}, \ldots, w_{n}^{*}\right)$. To determine the optimal weight for each pair of attributes, we should have $w_{B} / w_{j}=a_{B j}$ and $w_{j} / w_{W}=a_{j W}$. To meet these conditions for all $\mathrm{j}$, there must be a solution in which the maximum absolute differences $\left|w_{B} / w_{j}-a_{B j}\right|$ and $\left|w_{j} / w_{W}-a_{j W}\right|$ for all $j$ are minimized. Considering the non-negativity of weights and their sum, the model can be formulated as follows:

$$
\begin{aligned}
& \min _{j} \max _{j}\left\{\left|\frac{w_{B}}{w_{j}}-a_{B j}\right|,\left|\frac{w_{j}}{w_{W}}-a_{j W}\right|\right\} \\
& \text { s.t. } \\
& \sum_{j} w_{j}=1 \\
& w_{j} \geq 0, \quad \text { for all } j
\end{aligned}
$$

Additionally, the above model can be transformed into the following:

$$
\begin{aligned}
& \min \xi \\
& \text { s.t. } \\
& \left|\frac{w_{B}}{w_{j}}-a_{B j}\right| \leq \xi, \quad \text { for all } j \\
& \frac{w_{j}}{w_{W}}-a_{j W} \mid \leq \xi, \quad \text { for all } j \\
& \sum_{j} w_{j}=1 \\
& w_{j} \geq 0, \quad \text { for all } j
\end{aligned}
$$

By solving the above model, the optimal values of $\left(w_{1}^{*}, w_{2}^{*}, \ldots, w_{n}^{*}\right)$ and $\xi^{*}$ will be obtained. Moreover, using the obtained $\xi^{*}$, the consistency index (CI) can be calculated. It is obvious that the higher value for $\xi^{*}$ indicates the higher consistency ratio. Since $a_{B j} \times a_{j W}=a_{B W}$ and $a_{B W} \in\{1,2, \ldots, 9\}$, the maximum value of $\xi^{*}$ could be obtained. Then, using the consistency index values which are shown in Table 1 and employing Equation (3), the consistency ratio can also be obtained.

$$
\text { Consistency Ratio }=\frac{\xi^{*}}{\text { Consistency Index }}
$$

Table 1. The consistency index (CI) used in the best-worst method (BWM) approach [45].

\begin{tabular}{cccccccccc}
\hline $\boldsymbol{a}_{\boldsymbol{B W}}$ & $\mathbf{1}$ & $\mathbf{2}$ & $\mathbf{3}$ & $\mathbf{4}$ & $\mathbf{5}$ & $\mathbf{6}$ & $\mathbf{7}$ & $\mathbf{8}$ & $\mathbf{9}$ \\
\hline Consistency index & 0.00 & 0.44 & 1.00 & 1.63 & 2.30 & 3.00 & 3.73 & 4.47 & 5.23 \\
\hline
\end{tabular}

\subsection{Weighted Aggregated Sum Product Assessment (WASPAS)}

Multicriteria support systems can successfully be used for complex real-world decisions, where different options should be examined based on a large number of criteria. Multiple criteria decision-making (MCDM) methods based on various parameters have been used in many studies [46,47]. One of the parameters that can be considered in choosing a multicriteria decision-making method is the accuracy of these models. Researchers also suggest that combining two models can increase their accuracy [48]. The accuracy of the results from the WSM (weighted sum model) and WPM (weighted product model) multiattribute decision models is relatively well-known. In addition, the accuracy of the combined models has also been analyzed by the researchers. Researchers have confirmed that the accuracy of the hybrid models is much higher than that of the models before they are combined. One of 
these models is the weighted aggregated sum product assessment (WASPAS) model, which can have high efficiency in complex decision-making issues and result in accurate outputs.

The weighted sum model is one of the best-known decision-making models in solving multicriteria problems. A multicriteria problem is being defined by $m$ options (alternatives) and $n$ decision criteria. $w_{j}$ represents the relative importance of the criterion and $x_{i j}$ is the performance value of alternative $i$ in terms of criterion $j$. Therefore, the relative importance of alternative $i$ in Equation (4) is shown as $Q_{i}^{(1)}$, where $\bar{x}_{i j}$ is defined as the normalized value of the $j$-th criterion of alternative $i[49,50]$.

$$
Q_{i}^{(1)}=\sum_{j=1}^{n} \bar{x}_{i j} \times w_{j}
$$

Based on the weighted product model, the relative importance of alternative $i$ is given as $Q_{i}^{(2)}$, which is defined as demonstrated in Equation (5) [51,52].

$$
Q_{i}^{(2)}=\max \prod_{j=1}^{n}\left(\bar{x}_{i j}\right)^{w_{j}}
$$

As demonstrated in Equation (6), it has been attempted to determine the final significance of each alternative by a combination of criteria, in which an even share of WSM and WPM is given for the final evaluation of alternatives [53].

$$
\begin{aligned}
& Q_{i}=0.5 Q_{i}^{(1)}+0.5 Q_{i}^{(2)} \\
& Q_{i}=\lambda \sum_{j=1}^{n} \bar{x}_{i j} w_{j}+(1-\lambda) \prod_{j=1}^{n}\left(\bar{x}_{i j}\right)^{w_{j}}, \quad \lambda=0, \ldots, 1
\end{aligned}
$$

The optimal values of $\lambda$ can be calculated by expanding the following equation:

$$
\lambda=\frac{\delta^{2}\left(Q_{i}^{(2)}\right)}{\delta^{2}\left(Q_{i}^{(1)}\right)+\delta^{2}\left(Q_{i}^{(2)}\right)},
$$

where $\delta^{2}\left(Q_{i}^{(1)}\right)$ and $\delta^{2}\left(Q_{i}^{(2)}\right)$ must be calculated from Equations (8) and (9):

$$
\begin{gathered}
\delta^{2}\left(Q_{i}^{(1)}\right)=\sum_{j=1}^{n} \bar{x}_{i j} w_{j}^{2} \delta^{2}\left(\bar{x}_{i j}\right), \\
\delta^{2}\left(Q_{i}^{(2)}\right)=\sum_{j=1}^{n}\left[\frac{\prod_{j=1}^{n}\left(\bar{x}_{i j}\right)^{w_{j}} \times w_{i j}}{\left(\bar{x}_{i j}\right)^{w_{j}}\left(\bar{x}_{i j}\right)^{\left(1-w_{j}\right)}}\right]^{2} \delta^{2}\left(\bar{x}_{i j}\right),
\end{gathered}
$$

where the estimation of the variance of the primary normalized values of the criteria can also be calculated by the following equation:

$$
\delta^{2}\left(\bar{x}_{i j}\right)=\left(0.05 \bar{x}_{i j}\right)^{2} .
$$

\subsection{Methodology of This Research (BWM-WASPAS)}

With regard to all the explanations given in the previous sections, this study applied a combined BWM-WASPAS approach to evaluate the adherence of 8 populous Iranian cities in adopting and proper implementing of urban agriculture dimensions in order to move towards a sustainable society. First, by considering the dimensions of sustainable urban agriculture as the attributes of a multiattribute decision-making problem, the weights of each of these attributes were calculated using the best-worst 
method (BWM). Then, the weights obtained for each of the attributes were used to calculate the final value of each city using the WASPAS approach. Figure 2 summarizes the stages of the research.

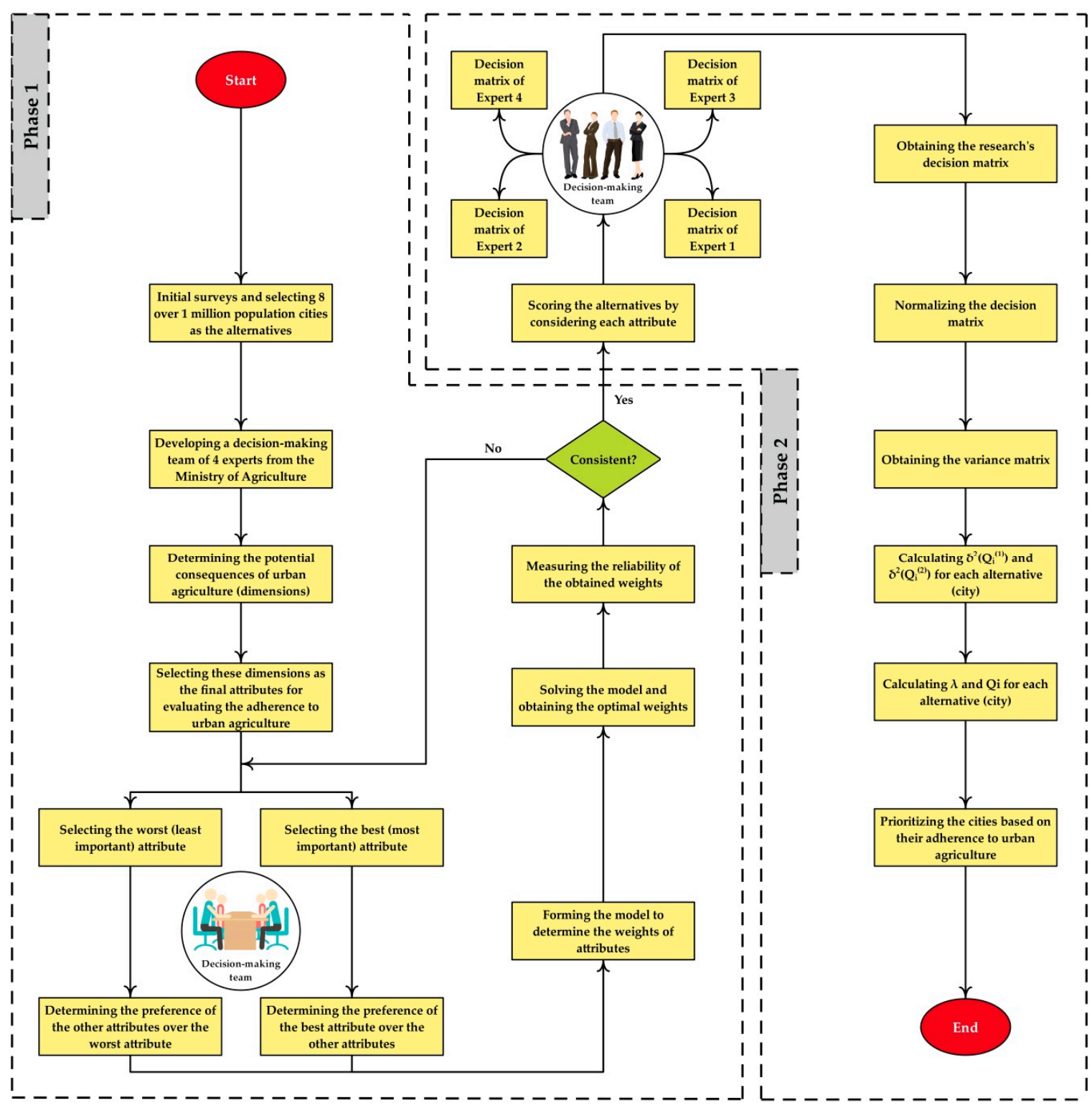

Figure 2. A brief summary of the research phases.

\section{Results and Discussion}

In this research, eight cities of Iran with a population of more than a million (Tehran $A_{1}$, Mashhad $A_{2}$, Isfahan $A_{3}$, Karaj $A_{4}$, Shiraz $A_{5}$, Tabriz $A_{6}$, Ahwaz $A_{7}$, and Qom $A_{8}$ ) were evaluated and prioritized by considering the opinions of four experts $E_{i}(i=1,2,3,4)$ from Iran's Ministry of Agriculture with respect to the five attributes (environmental $C_{1}$, socioeconomic $C_{2}$, vulnerable members empowerment $C_{3}$, training and culturizing $C_{4}$, and supply $C_{5}$ ). The experts of the decision-making team determined the best (most important) and worst (least important) attributes among the five attributes of the research. In this vein, given their experience and cognition of the government's macro policies, they selected the socioeconomic dimension as the most important dimension due to its vast impact on improving the economic indexes, social situations, and employment, and also, the supply dimension was selected as the least important dimension. Then, the preference vector of the best attribute (socio-economic dimension) over the other attributes and the 
preference vector of the other attributes over the worst attribute (supply dimension) were obtained. It should be noted that these preferences were formed using a 9-point scale (from 1 to 9 due to their importance). Figure 3 demonstrates the final decision of the experts' team in this regard.

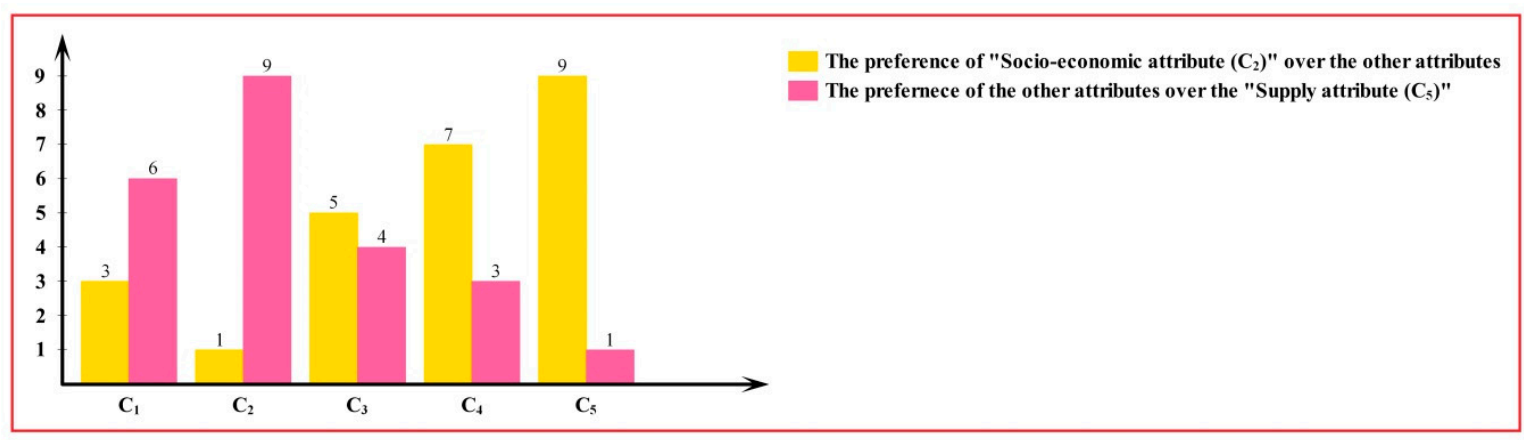

Figure 3. The preferences of the attributes according to the decion-making team.

Then, using the preferences obtained from the experts and applying Equations (1) and (2), the following model was created to calculate the weight associated with each of the attributes.

$$
\begin{gathered}
\min \xi \\
\text { s.t. } \\
\left|\frac{w_{2}}{w_{1}}-3\right| \leq \xi \quad \text { for all } j \\
\left|\frac{w_{2}}{w_{3}}-5\right| \leq \xi \quad \text { for all } j \\
\left|\frac{w_{2}}{w_{4}}-7\right| \leq \xi \quad \text { for all } j \\
\left|\frac{w_{2}}{w_{5}}-9\right| \leq \xi \quad \text { for all } j \\
\left|\frac{w_{1}}{w_{5}}-6\right| \leq \xi \quad \text { for all } j \\
\left|\frac{w_{3}}{w_{5}}-4\right| \leq \xi \quad \text { for all } j \\
\left|\frac{w_{4}}{w_{5}}-3\right| \leq \xi \quad \text { for all } j \\
w_{1}+w_{2}+w_{3}+w_{4}+\text { w } w_{5}=1 \\
w_{1}, w_{2}, w_{3}, w_{4}, w_{5} \geq 0 \quad \text { for all } j
\end{gathered}
$$

After that, by implementing the abovementioned model in the Lingo software, the optimal values of $\left(w_{1}^{*}, \ldots, w_{5}^{*}\right)$ and $\xi$ were computed, the results of which are shown in Table 2.

Table 2. The optimal values of $\left(w_{1}^{*}, \ldots, w_{5}^{*}\right)$ and $\xi$ for the attributes.

\begin{tabular}{ccccccc}
\hline Variable & $w_{1}$ & $w_{2}$ & $w_{3}$ & $w_{4}$ & $w_{5}$ & $\xi$ \\
\hline value & 0.2307 & 0.4997 & 0.1335 & 0.0870 & 0.0487 & 1.2583 \\
\hline
\end{tabular}

Based on the BWM decision approach, the more consistency ratios are closer to zero, the more consistent results also are [45], and getting CR values less than 0.25 shows a high degree of consistency and reliability [54]. In this model, given that the value of $a_{B W}$ is equal to 9 , its corresponding consistency index according to Table 1 is 5.23, and by plugging in this value and the obtained value of $\xi(1.2583)$ in Equation (3), the consistency ratio was calculated. As 0.2405 is less than 0.25 , this indicates the high reliability and accuracy of the achieved weights. Subsequently, decision-making team members were asked to assign a score to each city by considering each of the attributes based on a 9-point scale 
(from very bad as 1 to very good as 9). The result of this scoring was obtaining the decision-making matrix, based on averaging the opinions of the experts, which is shown as Table 3.

Table 3. The initial decision matrix based on the opinions of all experts.

\begin{tabular}{cccccc}
\hline Cities & $\mathbf{C}_{\mathbf{1}}$ & $\mathbf{C}_{\mathbf{2}}$ & $\mathbf{C}_{\mathbf{3}}$ & $\mathbf{C}_{\mathbf{4}}$ & $\mathbf{C}_{\mathbf{5}}$ \\
\hline Tehran $\left(\mathrm{A}_{1}\right)$ & 4 & 6.25 & 4.25 & 4.75 & 4.75 \\
Mashhad $\left(\mathrm{A}_{2}\right)$ & 4.5 & 4.25 & 4.75 & 6 & 4.5 \\
Isfahan $\left(\mathrm{A}_{3}\right)$ & 4.25 & 5 & 5.25 & 5.25 & 4.5 \\
Karaj $\left(\mathrm{A}_{4}\right)$ & 3.25 & 4 & 3.5 & 3.25 & 2.75 \\
Shiraz $\left(\mathrm{A}_{5}\right)$ & 4.75 & 5.5 & 5.75 & 5 & 5.25 \\
Tabriz $\left(\mathrm{A}_{6}\right)$ & 6 & 5.25 & 6.25 & 6.25 & 5 \\
Ahwaz $\left(\mathrm{A}_{7}\right)$ & 2.75 & 3 & 3 & 3.5 & 3.25 \\
Qom $\left(\mathrm{A}_{8}\right)$ & 4 & 3.5 & 3.75 & 3.75 & 3.5 \\
\hline
\end{tabular}

Then, the decision matrix was normalized in Table 4.

Table 4. The normalized decision matrix of the research.

\begin{tabular}{cccccc}
\hline Cities & $\mathbf{C}_{\mathbf{1}}$ & $\mathbf{C}_{\mathbf{2}}$ & $\mathbf{C}_{\mathbf{3}}$ & $\mathbf{C}_{\mathbf{4}}$ & $\mathbf{C}_{\mathbf{5}}$ \\
\hline Tehran $\left(\mathrm{A}_{1}\right)$ & 0.32991 & 0.46953 & 0.32070 & 0.34730 & 0.39311 \\
Mashhad $\left(\mathrm{A}_{2}\right)$ & 0.37115 & 0.31928 & 0.35843 & 0.43869 & 0.37242 \\
Isfahan $\left(\mathrm{A}_{3}\right)$ & 0.35053 & 0.37562 & 0.39616 & 0.38385 & 0.37242 \\
Karaj $\left(\mathrm{A}_{4}\right)$ & 0.26806 & 0.30050 & 0.26410 & 0.23762 & 0.22759 \\
Shiraz $\left(\mathrm{A}_{5}\right)$ & 0.39177 & 0.41319 & 0.43389 & 0.36558 & 0.43449 \\
Tabriz $\left(\mathrm{A}_{6}\right)$ & 0.49487 & 0.39441 & 0.47161 & 0.45697 & 0.41380 \\
Ahwaz $\left(\mathrm{A}_{7}\right)$ & 0.22682 & 0.22537 & 0.22637 & 0.25590 & 0.26897 \\
Qom $\left(\mathrm{A}_{8}\right)$ & 0.32991 & 0.26294 & 0.28297 & 0.27418 & 0.28966 \\
\hline
\end{tabular}

After that, by having the weights of the attributes and the normalized decision matrix and using Equation (10), the variance values were calculated, as demonstrated in Table 5.

Table 5. The variances calculated for each city with respect to each attribute.

\begin{tabular}{cccccc}
\hline Cities & $\mathbf{C}_{\mathbf{1}}$ & $\mathbf{C}_{\mathbf{2}}$ & $\mathbf{C}_{\mathbf{3}}$ & $\mathbf{C}_{\mathbf{4}}$ & $\mathbf{C}_{\mathbf{5}}$ \\
\hline Tehran $\left(\mathrm{A}_{1}\right)$ & 0.00027 & 0.00055 & 0.00026 & 0.00030 & 0.00039 \\
Mashhad $\left(\mathrm{A}_{2}\right)$ & 0.00034 & 0.00025 & 0.00032 & 0.00048 & 0.00035 \\
Isfahan $\left(\mathrm{A}_{3}\right)$ & 0.00031 & 0.00035 & 0.00039 & 0.00037 & 0.00035 \\
Karaj $\left(\mathrm{A}_{4}\right)$ & 0.00018 & 0.00023 & 0.00017 & 0.00014 & 0.00013 \\
Shiraz $\left(\mathrm{A}_{5}\right)$ & 0.00038 & 0.00043 & 0.00047 & 0.00033 & 0.00047 \\
Tabriz $\left(\mathrm{A}_{6}\right)$ & 0.00061 & 0.00039 & 0.00056 & 0.00052 & 0.00043 \\
Ahwaz $\left(\mathrm{A}_{7}\right)$ & 0.00013 & 0.00013 & 0.00013 & 0.00016 & 0.00018 \\
Qom $\left(\mathrm{A}_{8}\right)$ & 0.00027 & 0.00017 & 0.00020 & 0.00019 & 0.00021 \\
\hline
\end{tabular}

Then, as demonstrated in Table 6 , the values of $\delta^{2}\left(Q_{i}^{(1)}\right)$ and $\delta^{2}\left(Q_{i}^{(2)}\right)$ were also calculated by Equations (8) and (9).

Table 6. The values of $\delta^{2}\left(Q_{i}^{(1)}\right)$ and $\delta^{2}\left(Q_{i}^{(2)}\right)$ for each city.

\begin{tabular}{cll}
\hline Cities & $\delta^{\mathbf{2}}\left(Q_{i}^{(\mathbf{1})}\right)$ & $\delta^{\mathbf{2}}\left(Q_{i}^{(\mathbf{2})}\right)$ \\
\hline Tehran $\left(\mathrm{A}_{1}\right)$ & 0.000072 & 0.000131 \\
Mashhad $\left(\mathrm{A}_{2}\right)$ & 0.000031 & 0.000100 \\
Isfahan $\left(\mathrm{A}_{3}\right)$ & 0.000043 & 0.000115 \\
Karaj $\left(\mathrm{A}_{4}\right)$ & 0.000021 & 0.000064 \\
Shiraz $\left(\mathrm{A}_{5}\right)$ & 0.000057 & 0.000137 \\
Tabriz $\left(\mathrm{A}_{6}\right)$ & 0.000061 & 0.000154 \\
Ahwaz $\left(\mathrm{A}_{7}\right)$ & 0.000010 & 0.000044 \\
Qom $\left(\mathrm{A}_{8}\right)$ & 0.000018 & 0.000066 \\
\hline
\end{tabular}


Finally, by computing the values of $\lambda$ using Equation (7) and obtaining the values of $Q_{i}$ using Equation (6), the final ranking of alternatives is as shown in Table 7.

Table 7. The final ranking of cities based on adherence to urban agriculture.

\begin{tabular}{cccc}
\hline Cities & $\lambda$ & $Q_{i}$ & Ranking \\
\hline Tehran $\left(\mathrm{A}_{1}\right)$ & 0.644447 & 0.400935 & 3 \\
Mashhad $\left(\mathrm{A}_{2}\right)$ & 0.762997 & 0.348979 & 5 \\
Isfahan $\left(\mathrm{A}_{3}\right)$ & 0.728070 & 0.372993 & 4 \\
Karaj $\left(\mathrm{A}_{4}\right)$ & 0.756053 & 0.278818 & 7 \\
Shiraz $\left(\mathrm{A}_{5}\right)$ & 0.706405 & 0.407700 & 2 \\
Tabriz $\left(\mathrm{A}_{6}\right)$ & 0.715859 & 0.433603 & 1 \\
Ahwaz $\left(\mathrm{A}_{7}\right)$ & 0.819854 & 0.230517 & 8 \\
Qom $\left(\mathrm{A}_{8}\right)$ & 0.788520 & 0.283038 & 6 \\
\hline
\end{tabular}

It is obvious that the closer the value of $Q_{i}$ is to 1 , the greater the adherence it suggests to the urban agriculture policies by the cities. Based on the obtained rankings, the cities of Tabriz, Shiraz, and Tehran have the highest adherence to the implementation of urban agriculture policies. This means that, compared to the other cities studied, they have a better situation in terms of availability of existing cultural infrastructures for implementing urban agriculture and, despite the ambiguity of urban policies in this field, which are only limited to some general sentences on the paper, these cities are trying to synchronize themselves with this growing global trend that can save humanity and provide food security to cities, especially for the next generations. However, due to various international indexes, it should be noted that despite their high rankings in this evaluation system, the situation of these cities is still not satisfactory, and they are far from the international standards of urban agriculture and stepping towards sustainable development of the community. In order to solve this problem and fill the gap between the country's situation and international progress in this area, it is suggested that in addition to reforming the macro policies in the field of agriculture and promoting seriousness in the implementation of urban agriculture by authorities, the use of modern urban agriculture development methods must be put into action. One of these new approaches, which can contribute to the promotion of sustainable urban agriculture, is the proliferation of vertical farms in the cities. According to forecasts, the population of Iran will reach 100 million by the year 2022, which will reduce the average per capita available water resources. Therefore, using vertical farms can be very helpful for providing water and food requirements of this population, which uses modern irrigation methods in its production process.

By expanding the urban areas and energy consuming sectors in the country, energy consumption in all sectors (transportation, residential, commercial, industrial, and agricultural) has been increased and consequently, greenhouse emissions and air pollution have had a great impact on the health of the citizens. One of the ways that can be used to develop urban agriculture in major cities is vertical farming. Using this approach with regard to its benefits in removing fossil fuel consumption and producing food within buildings and under controlled conditions will reduce the amount of environmental pollution caused by agricultural activities. Furthermore, it has been found that the development and spatial distribution of cities and lack of proper planning for land use has destroyed the aesthetic aspects of cities and reduced the relationship between citizens and nature. In order to solve this problem, vertical farms can play an important role in increasing the level of greenness and establishing a link between residents and nature. With regard to the compact construction in urban spaces and reducing the amount of attention to the physical and psychological needs of the citizens, especially elderly people, building such farms in buildings can play an important role in increasing the amount of social interactions and creation of communal spaces. Indeed, rewriting old policies and updating them and taking into account the issues that citizens are dealing with can be a major step towards promoting the country in the field of food security. 
It should be noted that Iran is naturally dealing with water scarcity due to its climatic and geographical conditions. Due to the lack of up-to-date agricultural strategies and the excessive use of aquifers and the lack of proper educational programs for residents of different regions about the water crisis and proper management of water consumption, the crisis is on the rise day by day. It is obvious that this crisis affects agriculture and as a result, it also overshadows food security. Therefore, adopting a method that can be used to meet the food needs of citizens, regardless of the climate, can be very crucial for the country. Moreover, parts of the Iranian society are now aging, and this aging process is expanding rapidly. As an example, this phenomenon is seen in the agricultural sector's workforce and this is while the agricultural sector, in addition to this challenge, is also facing frustrated agricultural students. Therefore, despite the increasing number of graduates in this field, there is still a lack of skilled human resources in the country's agricultural sector. Thus, by preparing the possibility of working for these specialists by building vertical farms and creating a favorable biological environment in the community, it would be possible to influence the rate of improvement and economic growth in the cities of Iran.

\section{Conclusions}

Although urban agriculture is recognized as an emerging phenomenon in the process of sustainable urban development, due to the necessities mentioned in this research, it plays an important role in the future of urban planning and design. Designing productive cities and producing indigenous food industries is not a periodic approach, but it is considered as a central policy in the urban planning process. Meanwhile, the promotion of urban agriculture is one of the necessary strategies to stabilize this kind of development. The natural conditions of Iran and the severe water and soil constraints require a far greater perspective in the maintenance of agricultural lands than the experiences in developed countries. In urban agriculture, it should be noted that, firstly, the areas of urban agriculture are limited and largely unique. Secondly, urban gardens are a national wealth and belong to all people in society and in a sustainable way; future generations must safely take this precious heritage from us and should not be prevented from enjoying such delightful spaces.

Therefore, according to the characteristics of each city, various urban development patterns should be used to preserve agricultural lands and organize them. For example, in cities such as Qom and Ahwaz, which are facing water scarcity, agricultural policies need to be designed in ways that require less water. Furthermore, the policies that are being adopted should take into account the particular weather conditions of each city and encourage the development of plants that can grow in the weather of that particular region. Given to the rapid growth of cities and population in recent decades and the destruction of agricultural lands and gardens around cities, a need for more planning to control unbridled urban growth and provide food security for all citizens, especially in underdeveloped countries, is highly felt. The cities of Iran have also grown over the last few decades, and many of them were uncontrolled and out of place. This issue, coupled with an ever-increasing population, can create many problems in providing food for residents of large cities and keeping the urban air and environment clear. In fact, it can be stated that understanding factors such as food security, quality of living spaces, energy consumption, etc., as the critical issues of the region and prioritizing them according to their local significance can help the country's agricultural policies towards sustainable development to be updated. Although the country is far behind with the development of urban agriculture, it is never too late to reform the policies and remedy the shortcomings.

Funding: This research received no external funding.

Conflicts of Interest: The author declares no conflict of interest. 


\section{References}

1. Ali, S.H. Green Cities: Urban Growth and the Environment. J. Am. Plan. Assoc. 2008, 74, 143. [CrossRef]

2. Cohen, N.; Robbins, P. Green Cities: An A-to-Z Guide; SAGE Publications, Inc.: Thousand Oaks, CA, USA, 2011; ISBN 9781412996822.

3. Featherstone, J.; Cammarata, M.; Neukrug, H.; Devine, W. Creating a Sustainable City: Philadelphia's Green City Clean Waters Program. In Proceedings of the 47th ISOCARP Congress, Wuhan, China, 24-28 October 2011.

4. Latif, S.A.; Bidin, Y.H.; Awang, Z. Towards the Realization of Green Cities: The Moderating Role of the Residents' Education Level. Procedia Soc. Behav. Sci. 2013, 85, 646-652. [CrossRef]

5. Pojani, D.; Stead, D.; Pojani, D.; Stead, D. Sustainable Urban Transport in the Developing World: Beyond Megacities. Sustainability 2015, 7, 7784-7805. [CrossRef]

6. Mohiuddin, M.; Al Mamun, A.; Syed, F.; Mehedi Masud, M.; Su, Z.; Mohiuddin, M.; Al Mamun, A.; Syed, F.A.; Mehedi Masud, M.; Su, Z. Environmental Knowledge, Awareness, and Business School Students' Intentions to Purchase Green Vehicles in Emerging Countries. Sustainability 2018, 10, 1534. [CrossRef]

7. McColl, K. Can we feed the world? BMJ 2008, 336, 1336-1338. [CrossRef] [PubMed]

8. Satterthwaite, D.; McGranahan, G.; Tacoli, C. Urbanization and its implications for food and farming. Philos. Trans. R. Soc. Lond. B. Biol. Sci. 2010, 365, 2809-2820. [CrossRef] [PubMed]

9. Mendes, W.; Balmer, K.; Kaethler, T.; Rhoads, A. Using Land Inventories to Plan for Urban Agriculture: Experiences From Portland and Vancouver. J. Am. Plan. Assoc. 2008, 74, 435-449. [CrossRef]

10. Zezza, A.; Tasciotti, L. Urban agriculture, poverty, and food security: Empirical evidence from a sample of developing countries. Food Policy 2010, 35, 265-273. [CrossRef]

11. Mougeot, L.J.A. Urban Agriculture: Definition, Presence, Potentials and Risks, and Policy Challenges; International Development Research Centre: Ottawa, ON, Canada, 2000; pp. 1-42.

12. Ferreira, A.J.D.; Guilherme, R.I.M.M.; Ferreira, C.S.S.; de Oliveira, M.d.F.M.L. Urban agriculture, a tool towards more resilient urban communities? Curr. Opin. Environ. Sci. Health 2018, 5, 93-97. [CrossRef]

13. Vieira, L.C.; Serrao-Neumann, S.; Howes, M.; Mackey, B. Unpacking components of sustainable and resilient urban food systems. J. Clean. Prod. 2018, 200, 318-330. [CrossRef]

14. Burgin, S. 'Back to the future'? Urban backyards and food self-sufficiency. Land Use Policy 2018, 78, $29-35$. [CrossRef]

15. De Temmerman, J. Feasibility of Urban Agriculture in Brussels: A Qualitative Multi-Stakeholder Analysis. Master's Thesis, Ghent University, Gent, Belgium, 2013.

16. Wekerle, G.R. Food Justice Movements. J. Plan. Educ. Res. 2004, 23, 378-386. [CrossRef]

17. Game, I.; Primus, R. Urban Agriculture; State University of New York: Albany, NY, USA, 2015.

18. Cadigan, J. Urban Agriculture: A Key Element of Food System Planning in the United States; American Planning Association: Chicago, IL, USA, 2011.

19. Van Veenhuizen, R. Cities Farming for the Future: Urban Agriculture for Green and Productive Cities; International Institute of Rural Reconstruction, International Development Research Centre: Ottawa, ON, Canada, 2006; ISBN 1930261144.

20. Williams, N.S.G.; Rayner, J.P.; Raynor, K.J. Green roofs for a wide brown land: Opportunities and barriers for rooftop greening in Australia. Urban For. Urban Green. 2010, 9, 245-251. [CrossRef]

21. Despommier, D. Farming up the city: The rise of urban vertical farms. Trends Biotechnol. 2013, 31, 388-389. [CrossRef] [PubMed]

22. Specht, K.; Siebert, R.; Hartmann, I.; Freisinger, U.B.; Sawicka, M.; Werner, A.; Thomaier, S.; Henckel, D.; Walk, H.; Dierich, A. Urban agriculture of the future: An overview of sustainability aspects of food production in and on buildings. Agric. Hum. Values 2014, 31, 33-51. [CrossRef]

23. Garg, A.; Balodi, R. Recent trends in agriculture: Vertical farming and organic farming. Adv. Plants Agric. Res. 2014, 1, 142-144. [CrossRef]

24. Despommier, D.D. The Vertical Farm: Feeding the World in the 21st Century; Picador: London, UK, 2010; ISBN 9780312610692.

25. Viljoen, A.; Bohn, K.; Howe, J. Continuous Productive Urban Landscapes: Designing Urban Agriculture for Sustainable Cities; Architectural Press: New York, NY, USA, 2005; ISBN 0750655437. 
26. Maye, D. 'Smart food city': Conceptual relations between smart city planning, urban food systems and innovation theory. City Cult. Soc. 2018. [CrossRef]

27. Yang, Z.; Cai, J.; Sliuzas, R. Agro-tourism enterprises as a form of multi-functional urban agriculture for peri-urban development in China. Habitat Int. 2010, 34, 374-385. [CrossRef]

28. Markham, B.L. Mini Farming: Self Sufficiency on a 1/4 Acre; Skyhorse Pub: New York, NY, USA, 2010; ISBN 9781602399846.

29. Grewal, S.S.; Grewal, P.S. Can cities become self-reliant in food? Cities 2012, 29, 1-11. [CrossRef]

30. Altieri, M.A.; Companioni, N.; Cañizares, K.; Murphy, C.; Rosset, P.; Bourque, M.; Nicholls, C.I. The greening of the "barrios": Urban agriculture for food security in Cuba. Agric. Hum. Values 1999, 16, 131-140. [CrossRef]

31. Burton, P.; Lyons, K.; Richards, C.; Amati, M.; Rose, N.; Fours, L.D.; Pires, V.; Barclay, R. Urban Food Security, Urban Resilience and Climate Change; National Climate Change Adaptation Research Facility: Southport, QLD, Australia, 2013; ISBN 9781921609909.

32. Kremen, C.; Miles, A. Ecosystem Services in Biologically Diversified versus Conventional Farming Systems: Benefits, Externalities, and Trade-Offs. Ecol. Soc. 2012, 17, art40. [CrossRef]

33. Méndez, V.E.; Bacon, C.M.; Cohen, R.; Gliessman, S.R. Agroecology: A Transdisciplinary, Participatory and Action-Oriented Approach; CRC Press: Boca Raton, FL, USA, 2015; ISBN 9781482241761.

34. Sumner, J.; Mair, H.; Nelson, E. Putting the culture back into agriculture: Civic engagement, community and the celebration of local food. Int. J. Agric. Sustain. 2010, 8, 54-61. [CrossRef]

35. Nettle, C. Community Gardening as Social Action; Routledge: Abingdon, UK, 2014; ISBN 1409455866.

36. Mougeot, L.J.A. Growing Better Cities: Urban Agriculture for Sustainable Development; International Development Research Centre: Ottawa, ON, Canada, 2006; ISBN 1552502260.

37. Gupta, H. Assessing organizations performance on the basis of GHRM practices using BWM and Fuzzy TOPSIS. J. Environ. Manag. 2018, 226, 201-216. [CrossRef] [PubMed]

38. Rezaei, J.; Kothadiya, O.; Tavasszy, L.; Kroesen, M. Quality assessment of airline baggage handling systems using SERVQUAL and BWM. Tour. Manag. 2018, 66, 85-93. [CrossRef]

39. Gupta, H. Evaluating service quality of airline industry using hybrid best worst method and VIKOR. J. Air Transp. Manag. 2018, 68, 35-47. [CrossRef]

40. Wang, Z.; Xu, G.; Lin, R.; Wang, H.; Ren, J. Energy performance contracting, risk factors, and policy implications: Identification and analysis of risks based on the best-worst network method. Energy 2019, 170, 1-13. [CrossRef]

41. Gupta, H.; Barua, M.K. A framework to overcome barriers to green innovation in SMEs using BWM and Fuzzy TOPSIS. Sci. Total Environ. 2018, 633, 122-139. [CrossRef]

42. Rezaei, J.; van Roekel, W.S.; Tavasszy, L. Measuring the relative importance of the logistics performance index indicators using Best Worst Method. Transp. Policy 2018, 68, 158-169. [CrossRef]

43. Badri Ahmadi, H.; Kusi-Sarpong, S.; Rezaei, J. Assessing the social sustainability of supply chains using Best Worst Method. Resour. Conserv. Recycl. 2017, 126, 99-106. [CrossRef]

44. Ren, J.; Liang, H.; Chan, F.T.S. Urban sewage sludge, sustainability, and transition for Eco-City: Multi-criteria sustainability assessment of technologies based on best-worst method. Technol. Forecast. Soc. Chang. 2017, 116, 29-39. [CrossRef]

45. Rezaei, J. Best-worst multi-criteria decision-making method. Omega 2015, 53, 49-57. [CrossRef]

46. Simanaviciene, R.; Ustinovicius, L. A New Approach to Assessing the Biases of Decisions based on Multiple Attribute Decision making Methods. Electron. Electr. Eng. 2012, 117, 29-32. [CrossRef]

47. Ginevičius, R. A new determining method for the criteria weights in multicriteria evaluation. Int. J. Inf. Technol. Decis. Mak. 2011, 10, 1067-1095. [CrossRef]

48. Zavadskas, E.K.; Turskis, Z.; Antucheviciene, J.; Zakarevicius, A. Optimization of Weighted Aggregated Sum Product Assessment. Electron. Electr. Eng. 2012, 122, 3-6. [CrossRef]

49. Fishburn, P.C. Additive Utilities with Incomplete Product Sets: Application to Priorities and Assignments. Oper. Res. 1967, 15, 537-542. [CrossRef]

50. Triantaphyllou, E. Multi-Criteria Decision Making: A Comparative Study; Kluwer Academic Publishers: Dordrecht, The Netherlands, 2000.

51. Miller, D.; Starr, M. Executive Decisions and Operations Research; Prentice-Hall, Inc.: Englewood Cliffs, NJ, USA, 1969.

52. Bridgman, P. Dimensional Analysis; Yale University Press: New Haven, CT, USA, 1992. 
53. Šaparauskas, J.; Zavadskas, E.K.; Turskis, Z. Selection of facade's alternatives of commercial and public buildings based on multiple criteria/komercinès ir viešosios paskirties pastatu fasado alternatyvu daugiakriterinè atranka. Int. J. Strateg. Prop. Manag. 2011, 15, 189-203. [CrossRef]

54. Rezaei, J. Best-worst multi-criteria decision-making method: Some properties and a linear model. Omega 2016, 64, 126-130. [CrossRef]

(C) 2019 by the author. Licensee MDPI, Basel, Switzerland. This article is an open access article distributed under the terms and conditions of the Creative Commons Attribution (CC BY) license (http://creativecommons.org/licenses/by/4.0/). 